\title{
MODEL TES DAN ANALISIS PRESTASI BELAJAR MATEMATIK SISWA SEKOLAH DASAR
}

\author{
Zamsir \\ FKIP Universitas Haluoleo \\ zam1307@gmail.com
}

\begin{abstract}
Abstrak
Penelitian ini bertujuan untuk menemukan model tes dan analisis prestasi belajar siswa yang dapat dipakai untuk melakukan identifikasi level kemampuan dan menyusun profil pencapaian kompetensi siswa, khususnya di sekolah dasar. Penelitian ini merupakan penelitian pengembangan model yang dikembangkan menyangkut dua hal, yaitu: (1) prosedur dan langkahlangkah penyusunan tes serta teknik identifikasi level kemampuan siswa, dan (2) pelaporan hasil tes. Identifikasi dilakukan dengan cara menempatkan posisi aspek-aspek kemampuan yang diujikan dan kemampuan (ability) siswa ke dalam level-level kemampuan tertentu. Level kemampuan terdiri dari 4 level, yaitu: Level I, Level II, Level III, dan Level IV. Level I merupakan level terendah dan Level IV merupakan level tertinggi. Hasil penelitian berupa produk model tes dan analisis prestasi belajar siswa yang memiliki dua komponen, yaitu: (1) manual prosedur dan langkah-langkah penyusunan tes serta teknik identifikasi level kemampuan siswa, dan (2) format pelaporan hasil tes. Berdasarkan hasil analisis data pada uji coba diperluas disimpulkan bahwa: (1) persentase posisi level aspek-aspek kemampuan pada semua level untuk ketiga paket tes yang diujikan memenuhi kurva normal, yakni sebanyak 21,2\% Level I; 28,2\% Level II; 34,1\% Level III, dan 16,5\% Level IV. (2) Hasil identifikasi level kemampuan siswa menunjukkan bahwa sebagian besar siswa mempunyai kemampuan pada Level I dan Level II, yakni sebanyak 70,17\%. Siswa yang mempunyai kemampuan pada Level III dan Level IV hanya 29,,83\%. Proporsi siswa yang memiliki kemampuan pada Level I, Level II, Level III, dan Level IV adalah 0,3: 0,4: 02: 0,1.
\end{abstract}

Kata kunci: model, tes, penilaian, kompetensi 
Jurnal Penelitian dan Evaluasi Pendidikan

\title{
A TEST MODEL AND AN ANALYSIS OF STUDENTS' MATHEMATICS ACHIEVEMENT IN ELEMENTARY SCHOOLS
}

\author{
Zamsir \\ FKIP Universitas Haluoleo \\ zam1307@gmail.com
}

\begin{abstract}
This study aims to find out a model of a test and an analysis of students' achievement that can be applied to identify the ability levels and to construct the profiles of the students' competence attainment, especially in elementary schools. This research is research and development (R\&D. The model to be developed deals with two aspects, i.e.: (1) the procedure and steps in designing the test and techniques to identify students' ability levels, and (2) the test result reporting. The identification is conducted by classifying the positions of the tested ability aspects and the students' ability into ability levels. The ability is classified into 4 levels, i.e. Level I, Level II, Level III, and Level IV. Level I is the lowest level and Level IV is the highest level. The research product is in the form of a model of a test and an analysis of students' achievement with two components, i.e.: (1) a manual consisting of the procedure and steps to construct a test and techniques to identify the levels of students' ability, and (2) a format of test result reporting. Based on the results of the analysis of the data from the large-scale tryout, it can be concluded as follows. (1) The percentages of the level position of the ability aspects in all levels for the three administered test packages show normal curve, namely 21,2\% for Level I, $28,2 \%$ for Level II, 34,1\% for Level III, and 16,5\% for Level IV. (2) The results of the identification of the student ability levels show that most students $(70,17 \%)$ have the ability in Level I and Level II. There are only $29,83 \%$ of the students who have the ability in Level III and Level IV. The proportion of the students who have the ability in Level I, Level II, Level III, and Level IV is 0,3: 0.4: 0,2: 0,1.
\end{abstract}

Keywords: model, test, assesment, competence

594 - Jurnal Penelitian dan Evaluasi Pendidikan Tahun 16, Nomor 2, 2012 


\section{Pendahuluan}

Implementasi asesmen pada tingkat sekolah dasar dan menengah selalu mengalami perubahan seiring dengan perubahan kurikulum yang dilakukan oleh pemerintah dalam hal ini Kemendikbud. Perubahan ini tidak hanya menyangkut tentang model dan sistem asesmen yang diterapkan tetapi juga menyangkut pengambilan keputusan terhadap hasil asesmen.

Asesmen diartikan sebagai prosedur yang digunakan untuk mendapatkan informasi tentang prestasi atau kinerja seseorang yang hasilnya akan digunakan untuk evaluasi (Popham, 1995). Asesmen adalah proses dari pengumpulan informasi guna membuat keputusan. Asesmen dilakukan untuk mengetahui seberapa tinggi kinerja atau prestasi seseorang. Informasi tersebut diperoleh dari data yang diperoleh melalui kegiatan pengukuran baik menggunakan tes maupun non tes (Anderson, 2003).

Asesmen juga memiliki terminologi khusus guna mendeskripsikan semua aktivitas yang dikerjakan oleh guru untuk mendapatkan informasi tentang pengetahuan, keterampilan dan sikap dari siswa. Pengumpulan data melalui tes objektif dan observasi atau daftar isian termasuk aktivitas asesmen (Marsh, 1996). Menurut Popham (1995) alasan perlunya melakukan asesmen adalah untuk: (1) mendiagnosa kekuatan dan kelemahan siswa, (2) memantau kemajuan belajar siswa, (3) memberi atribut penilaian, dan (4) menentukan efektivitas pengajaran.

Herman, Aschbacher dan Winters (1992) menyatakan dua tujuan yang paling dasar dilakukan asesmen, yaitu untuk (1) menentukan sejauhmana siswa telah menguasai pengetahuan atau keterampilanketerampilan, dan (2) mendiagnosa kelemahan dan kelebihan siswa dan merancang pengajaran yang sesuai. Terkait dengan tujuan pertama, asesmen harus difokuskan kepada hasil belajar dengan menggunakan tes dan asesmen langsung terhadap proyek atau produk karya siswa. Untuk tujuan kedua, asesmen difokuskan kepada perhatian tentang pengalaman mengapa siswa berbuat salah, sehingga yang dibutuhkan adalah informasi tentang proses daripada hasil belajar. Oleh karena itu, teknik-teknik yang tepat digunakan antara lain wawancara, observasi, jurnal 
siswa atau evaluasi diri, daftar isian, dan pemikiran-pemikiran siswa mengenai proses belajarnya.

Asesmen kompetensi menurut Wolf 1995 dalam (Asmawi Zainul, 2004) pada garis besarnya terdiri dari komponen-komponen: (1) tujuan yang harus dinyatakan secara akurat dan dalam terminologi tingkah laku, (2) kriteria untuk asesmen harus dinyatakan secara terbuka dan eksplisit, (3) penolakan terhadap penetapan masa belajar dan persyaratan masukan bagi calon siswa, (4) persyaratan kelulusan adalah kemampuan mendemonstrasikan kompetensi dalam profesinya, (5) asesmen kebutuhan (need assessment) menjadi suatu yang esensial untuk mengidentifikasi kompetensi siswa, dan (6) personalisasi program pembelajaran dan individualisasi asesmen.

Karaktersitik asesmen berbasis kompetensi perlu diketahui guna merancang program pembelajaran dan sistem asesmen yang tepat. Djemari Mardapi (2004: 5) mengemukakan karakteristik asesmen berbasis kompetensi, meliputi: (1) hasil belajar merupakan kemampuan atau kompetensi yang dapat didemonstrasikan, (2) kecepatan belajar siswa berbeda dalam mencapai ketuntasan belajar, (3) asesmen hasil belajar menggunakan acuan kriteria, (4) adanya program pembelajaran remidi dan pengayaan, (5) guru merancang pengalaman belajar siswa, (6) guru adalah fasilitator, dan (7) pembelajaran mencakup aspek afektif yang terintegrasi dalam semua bidang studi.

Lebih lanjut Djemari Mardapi (2004) mengemukakan tentang prinsip yang harus diperhatikan dalam asesmen. Prinsip asesmen yang penting adalah akurat, ekonomis, dan mendorong peningkatan kualitas pembelajaran. Oleh sebab itu, sistem asesmen yang digunakan disetiap lembaga pendidikan harus mampu: (1) memberi informasi yang akurat, (2) mendorong siswa belajar, (3) memotivasi guru, (4) meningkatkan kinerja lembaga, dan (5) meningkatkan kualitas pendidikan.

Prosedur asesmen berbasis kompetensi meliputi serangkaian kegiatan, yaitu: (a) menentukan kompetensi yang akan diases dan kriterianya, (b) mengumpulkan data berupa bukti-bukti kinerja dengan melalui kegiatan tes atau non tes, (c) mencocokkan bukti kinerja dengan kompetensi yang ingin dicapai, dan (d) mengklasifikasikan siswa menjadi 
kompeten dan belum kompeten berdasarkan bukti kinerjanya (Padmadewi, 2005: 456). Berdasarkan prosedur tersebut, siswa yang sudah kompeten atau menguasai materi yang diujikan dapat melanjutkan pembelajaran pada materi berikutnya, sedangkan yang belum menguasai (belum kompeten) diberikan remidi sampai mereka memenuhi indikator pencapaian kompetensi yang telah ditetapkan.

Prosedur asesmen berbasis kompetensi secara skematis dapat dilukiskan seperti pada Gambar 1 di bawah ini.

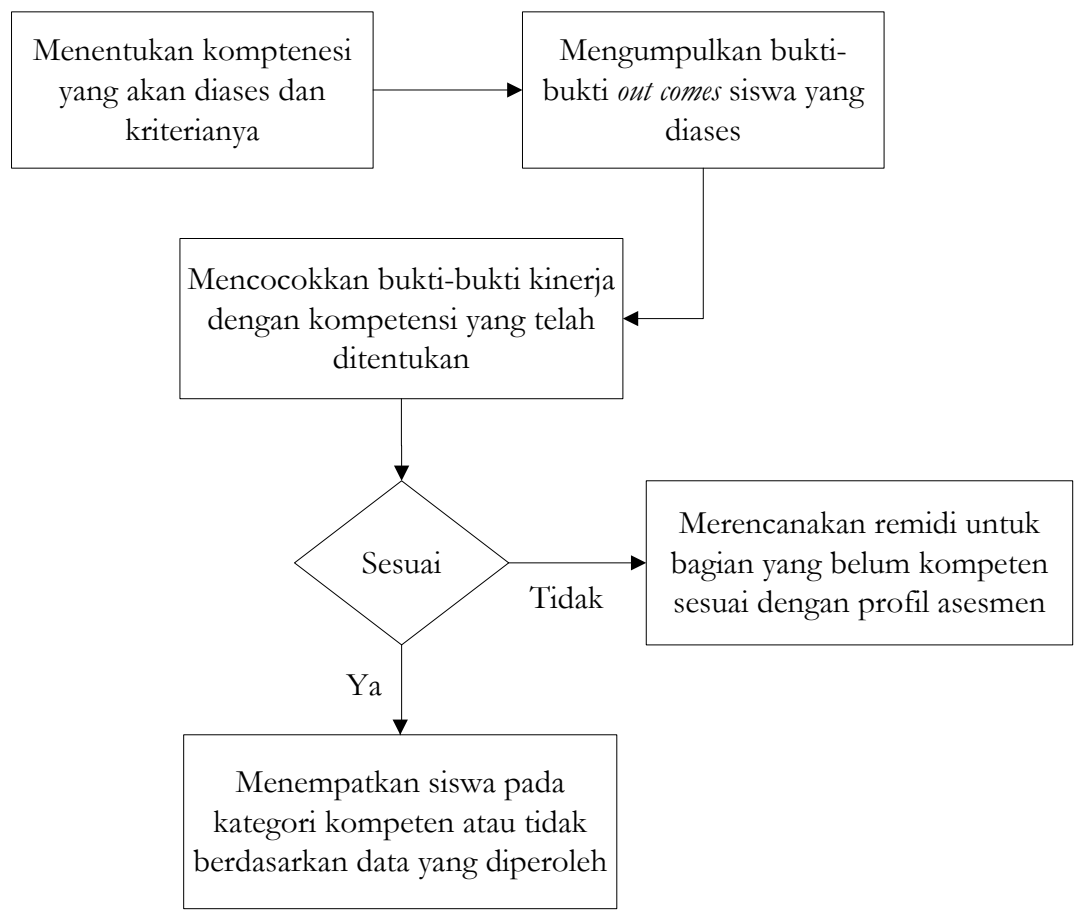

(Tim Fasilitator, 2005: 16)

Gambar 1. Prosedur Asesmen Berbasis Kompetensi 
Asesmen berbasis kompetensi berfokus pada kompetensi bukan pada masukan atau proses. Asesmen diarahkan untuk menentukan penguasaan siswa atas kompetensi yang harus dikuasainya, bukan pada bagaimana cara siswa mencapai tingkat penguasaan itu. Dengan kata lain, asesmen berbasis kompetensi lebih diarahkan pada penguasaan kompetensi sebagai hasil pembelajaran atau pendidikan dibandingkan dengan proses bagaimana siswa mencapai kompetensi tersebut.

Asesmen berbasis kompetensi ditujukan untuk menentukan apakah siswa telah atau belum menguasai kompetensi tertentu yang telah ditetapkan. Karena itu, asesmen berbasis kompetensi dilakukan untuk setiap siswa, bukan pada kemampuan kelompok atau kelas tertentu. Namun demikian, kegiatan asesmen bisa dilakukan dalam situasi kelompok, misalnya untuk mengakses kemampuan kerjasama dalam memecahkan suatu masalah tetapi sasaran penilaian tetap pada kemampuan setiap anggota kelompok secara individual.

Disamping itu, asesmen berbasis kompetensi tidak membandingkan keberhasilan seorang siswa dengan siswa lain. Dengan asesmen berbasis kompetensi memungkinkan siswa melakukan evaluasi diri (self evaluation). Asesmen berbasisi kompetensi bersifat terbuka, holistik, integratif dan otentik. Kelulusan siswa diperoleh jika semua standar atau kriteria kompetensi utama sudah dicapai (Hopkin,1992; O'malley \& Piere, 1996).

Untuk mengetahui seberapa jauh siswa telah menguasai kompetensi dasar perlu dikembangkan suatu sistem asesmen. Sistem asesmen yang dilakukan harus mencakup seluruh kompetensi dasar dengan menggunakan indikator yang telah ditetapkan. Indikator adalah gejala, perbuatan, atau respon yang ditunjukkan atau dilakukan oleh siswa berkaitan kompetensi dasar. Indikator menjadi pedoman pengukuran tingkat pencapaian belajar siswa sesuai kompetensi dasar yang harus dimiliki. Indikator ini menjadi salah satu acuan dalam membuat soal untuk mengukur pencapaian kemampuan siswa.

Penelitian ini bertujuan untuk: (1) menghasilkan model tes dan analisis prestasi belajar yang dapat dipakai untuk melakukan identifikasi level kemampuan siswa, dan (2) menghasilkan model pelaporan hasil tes 
yang dapat dipakai untuk mendeskripsikan level pencapaian kemampuan siswa.

\section{Metode Penelitian}

Penelitian ini menggunakan model penelitian dan pengembangan (Reserach and Develompment). Sampel uji coba instrumen sebanyak 180 orang siswa yang terdiri dari 60 orang siswa kelas III, 60 orang siswa kelas IV, dan 60 orang siswa kelas V. Sampel uji coba produk (uji impelemntasi) sebanyak 1.200 orang siswa dengan rincian sebanyak 400 siswa kelas III, 400 siswa kelas IV, dan 400 siswa kelas V. Jumlah sekolah yang dijadikan sampel uji coba produk sebanyak 10 SD Negeri. Pengumpulan data dilakukan dengan menggunakan teknik dokumentasi, wawancara, kuesioner/lembar penilaian, format kartu telaah soal, dan tes.

Data hasil uji coba instrumen tes dianalisis dengan menggunakan program MicroCat ITEMAN. Data hasil uji coba produk dianalisis dengan menggunakan program BIGSTEPS Versi 2.30 dan program SPSS for Windows 13.0. Selanjutnya, data lain yang diperoleh melalui observasi, wawancara, dan dokumentasi dianalisis dalam format deskriptif kualitatif dan kuantitatif, baik dalam bentuk narasi, tabel-tabel distribusi skor, grafik, diagram, persentase, dan rata-rata. Untuk keperluan tersebut digunakan statistik deskriptif.

Identifikasi level kemampuan dibuat dalam bentuk tingkatantingkatan atau level-level kemampuan atau benchmark. Setiap level memiliki sejumlah aspek kemampuan dan batas ambang (cut off value) yang berbedabeda. Penentuan banchmark mengkuti prosedur, yaitu: (1) mengidentifikasi aspek kemampuan yang akan dicapai, (2) mengidentifikasi langkah-langkah untuk menentukan kemampuan, dan (3) menggunakan berbagai pendekatan untuk menetapkan batas standar (Jackson \& D' Andrea, 2000: 89).

Identifikasi level kemampuan baik untuk level aspek kemampuan maupun kemampuan siswa dikelompokkan dalam 4 level, yaitu Level 1, Level 2, Level 3, dan Level 4. Level 1 merupakan level kemampuan paling rendah dan Level 4 merupakan level tertinggi. Level 1 pada aspek 
kemampuan terdiri dari butir-butir yang memiliki tingkat kesukaran rendah, sedangkan Level 4 terdiri dari butir-butir yang memiliki tingkat kesukaran tinggi. Penentuan posisi level kemampuan siswa memperhatikan pola jawaban benar dan kemampuan siswa memberikan respon benar sesuai dengan kriteria yang telah ditetapkan. Level 1 pada kemampuan siswa ditunjukkan oleh kemampuan siswa memberikan respon benar sekurangnkurangnya 75\% pada butir Level 1 dan kurang dari 75\% pada butir di level yang lainnya. Level 2 ditunjukkan oleh kemampuan siswa memberikan respon benar sekurangn-kurangnya 75\% pada butir Level 1 dan Level 2 dan kurang dari 75\% pada butir di level yang lainnya. Level 3 ditunjukkan oleh kemampuan siswa memberikan respon benar sekurangn-kurangnya 75\% pada butir Level 1 hingga Level 3, tetapi kurang dari 75\% pada butir di Level 4. Level 4 ditunjukkan oleh kemampuan siswa memberikan respon benar sekurangn-kurangnya $75 \%$ pada butir di semua level.

\section{Hasil dan Pembahasan}

\section{Hasil Validasi Perangkat Model dan Instrumen}

Produk hasil pengembangan dalam penelitian ini terdiri dari: (1) manual prosedur dan langkah-langkah penyusunan tes, teknik identifikasi level kemampuan, dan (2) format pelaporan hasil tes. Prosedur dan langkah-langkah penyusunan tes serta teknik identifikasi level kemampuan dikemas dalam satu paket yang disertasi dengan contoh penggunaannya. Paket manual prosedur dan langkah-langkah penyusunan tes ini sebelum digunakan, terlebih dahulu divalidasi oleh praktisi dan pakar (ahli pengukuran dan bidang studi). Hasil penilaian oleh pakar dan praktisi disimpulkan bahwa manual prosedur dan langkah-langkah penyusunan tes layak digunakan.

Format pelaporan hasil tes terdiri dari 2 (dua) komponen, yaitu: (1) pelaporan hasil tes kepada sekolah, dan (2) pelaporan kepada orang tua. Model pelaporan hasil tes ini sebelum menjadi master untuk diuji cobakan dan diimplementasikan terlebih dahulu divalidasi oleh praktisi (guru, kepala sekolah) dan pakar (ahli) dalam bidang studi serta dalam bidang 
pengukuran dan penilaian. Hasil penilaian oleh praktisi dan ahli terhadap model format pelaporan hasil tes yang dikembangkan dapat atau layak untuk digunakan.

Tes yang dikembangkan dalam penelitian ini terdiri dari tiga paket tes yaitu: (1) Tes Matematika Kelas III, (2) Tes Matematika Kelas IV, dan (3) Tes Matematika Kelas V. Berdasarkan analisis data hasil uji coba, diperoleh jumlah dan persentase soal-soal dalam kategori mudah, sedang, dan sukar disajikan pada Tabel 1 di bawah ini.

Tabel 1. Persentase Soal-Soal Menurut Kategori Mudah, Sedang, dan Sukar

\begin{tabular}{|c|c|c|c|c|c|c|c|}
\hline \multirow{2}{*}{ Nama Paket Tes } & \multirow{2}{*}{$\begin{array}{c}\text { Jumlah } \\
\text { Butir }\end{array}$} & \multicolumn{6}{|c|}{ Kategori Soal } \\
\cline { 3 - 8 } & & \multicolumn{2}{|c|}{ Mudah } & \multicolumn{2}{|c|}{ Sedang } & \multicolumn{2}{|c|}{ Sukar } \\
\cline { 3 - 8 } & & Jum & $\%$ & Jum & $\%$ & Jum & $\%$ \\
\hline Tes Mat. Kelas 3 & 30 & 8 & 26,7 & 17 & 56,7 & 5 & 16,7 \\
\hline Tes Mat. Kelas 4 & 35 & 8 & 22,9 & 21 & 60,0 & 6 & 17,1 \\
\hline Tes Mat. Kelas 5 & 35 & 9 & 25,7 & 20 & 57,1 & 6 & 17,1 \\
\hline
\end{tabular}

Berdasarkan tabel di atas terlihat bahwa Tes Matematika Kelas 3 terdiri 26,7\% soal-soalnya termuasuk kategori mudah, 56,7\% kategori sedang, dan 16,7\% kategori sukar. Tes Matematika Kelas 4 terdiri 22,9\% soal-soalnya termasuk kategori mudah, 60\% kategori sedang, dan 17,1\% kategori sukar. Tes Matematika Kelas 5 terdiri 25,7\% soal-soalnya termasuk kategori mudah, 57,1\% kategori sedang, dan 17,1\% kategori sukar.

Statistik karakteristik tes untuk ketiga paket tes yang dikembangkan, disajikan pada Tabel 2. Berdasarkan tabel tersebut terlihat bahwa ketiga perangkat instrumen tes tersebut memiliki tingkat kesukaran soal termasuk dalam kategori sedang dengan tingkat daya beda termasuk kategori cukup serta memiliki koefisien reliabilitas termasuk cukup handal (konsisten). Dengan demikian, ketiga paket tes tersebut layak digunakan dan sesuai 
dengan tingkat kemampuan siswa yang masih duduk dibangku sekolah dasar.

Tabel 2. Statistik Karakteristik Tes Matematika Kelas III, Kelas IV, dan Kelas V

\begin{tabular}{|l|c|c|c|}
\hline \multirow{2}{*}{ Statistik } & \multicolumn{3}{c|}{ Tes Matematika } \\
\cline { 2 - 4 } & Kelas III & Kelas IV & Kelas V \\
\hline Skor minimum & 8 & 9 & 10 \\
\hline Skor maksimum & 24 & 29 & 32 \\
\hline Skor maksimum ideal & 30 & 35 & 35 \\
\hline Nilai rerata & 16,367 & 18,767 & 20,583 \\
\hline Rerata Tingkat Kesukaran & 0,546 & 0,536 & 0,588 \\
\hline Rerata Daya Beda & 0,413 & 0,394 & 0,539 \\
\hline Standar deviasi & 4,363 & 4,821 & 6,793 \\
\hline $\begin{array}{l}\text { Kesalahan baku } \\
\text { pengukuran }\end{array}$ & 2,436 & 2,593 & 2,520 \\
\hline Koefisien reliabilitas & 0,788 & 0,711 & 0,862 \\
\hline
\end{tabular}

\section{Dekskripsi Data Hasil Uji Coba Produk}

a. Posisi level aspek kemampuan yang diujikan

Tes Matematika Kelas III terdiri 26 aspek kemampuan yang diujikan. Berdasarkan hasil identifikasi yang dilakukan diperoleh posisi level aspekaspek kemampuan yang diujikan, yaitu: sebanyak 23,1\% Level IV, sebanyak 30,8,\% Level III, sebanyak 26,9 Level; II, dan 19,2\% Level I. Jumlah butir soal yang mengukur setiap level kemampuan untuk aspek kemampuan yang diujikan adalah: Level IV sebanyak 6 butir, Level III sebanyak 8 butir, Level II sebanyak 7 butir, dan Level I sebanyak 5 butir. Selengkapnya, 
hierarki posisi level aspek-aspek kemampuan yang diujikan adalah sebagai berikut.

\section{Tabel 3. Hasil Tes Kelas III}

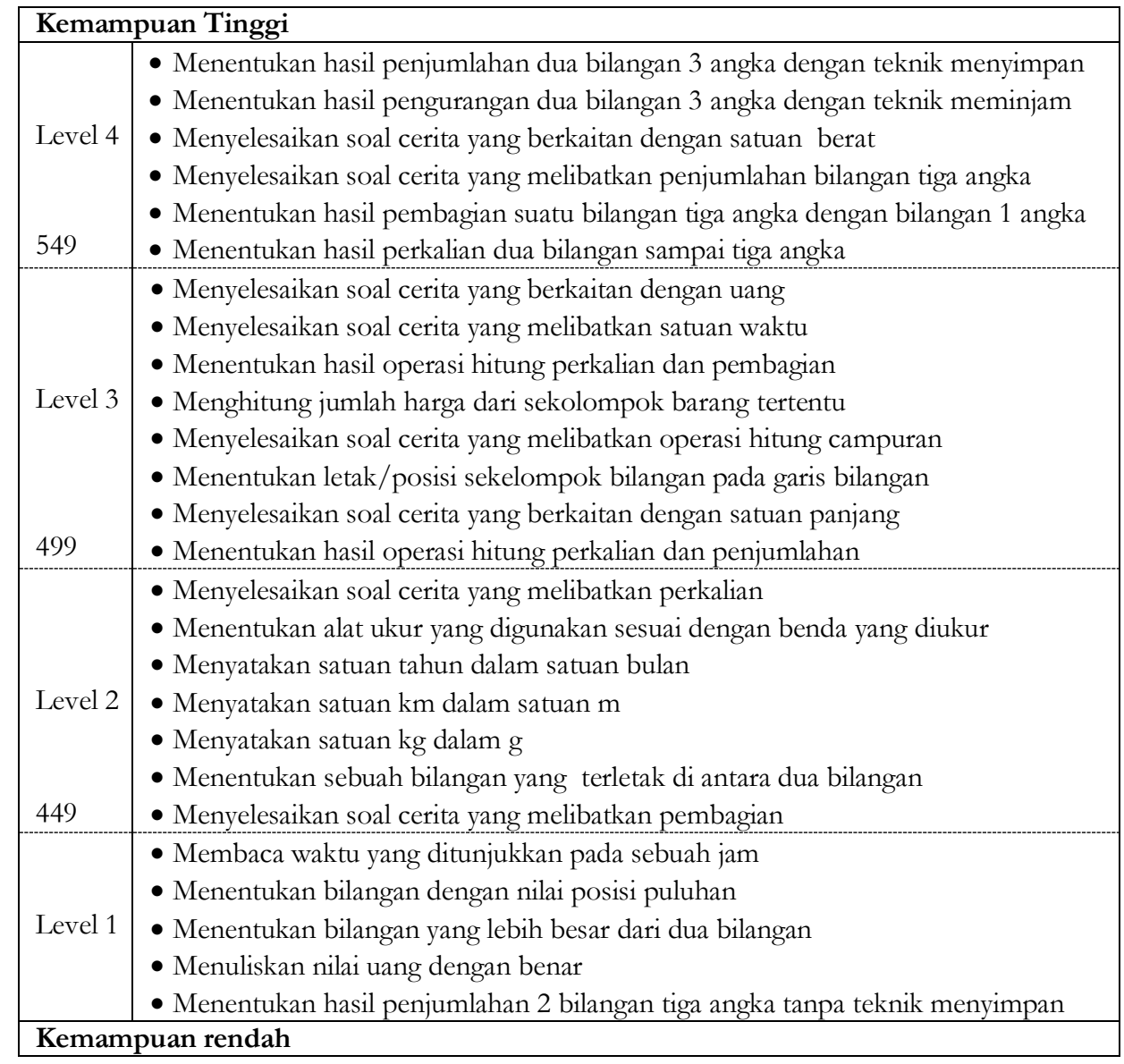

Tes Matematika Kelas IV terdiri 29 aspek kemampuan yang diujikan. Berdasarkan hasil identifikasi yang dilakukan diperoleh posisi level aspek-aspek kemampuan yang diujikan, yaitu: sebanyak 17,2\% Level IV, sebanyak 27,6,\% Level III, sebanyak 34,5 Level; II, dan 20,7\% Level I. Jumlah butir soal yang mengukur setiap level kemampuan untuk aspek 
kemampuan yang diujikan adalah: Level IV sebanyak 5 butir, Level III sebanyak 8 butir, Level II sebanyak 10 butir, dan Level I sebanyak 6 butir. Selengkapnya, hierarki posisi level aspek-aspek kemampuan yang diujikan adalah sebagai berikut.

\section{Tabel 4. Hasil Tes Kelas IV}

\begin{tabular}{|c|c|}
\hline \multicolumn{2}{|c|}{ Kemampuan Tinggi } \\
\hline $\begin{array}{l}\text { Level } 4 \\
559\end{array}$ & $\begin{array}{l}\text { - Menentukan KPK dari dua bilangan dengan faktorisasi prima } \\
\text { - Menentukan hasil bagi dan sisanya antara bilangan } 3 \text { dengan bilangan } 1 \text { angka } \\
\text { - Menyelesaikan soal cerita yang berkaitan dengan KPK } \\
\text { - Menentukan FPB dari dua bilangan dengan faktorisasi prima } \\
\text { - Menentukan FPB dari dua buah bilangan }\end{array}$ \\
\hline Level 3 & $\begin{array}{l}\text { - Menyelesaikan soal cerita yang melibatkan satuan waktu } \\
\text { - Menentukan hasil operasi hitung campuran } \\
\text { - Menentukan KPK dari dua bilangan } \\
\text { - Menentukan kelipatan persekutuan dari dua buah bilangan } \\
\text { - Menghitung luas segitiga } \\
\text { - Menghitung pembagian bilangan } 3 \text { angka dengan bilangan } 2 \text { angka } \\
\text { - Menyelesaikan soal cerita yang melibatkan satuan berat } \\
\text { - Menyelasaikan soal cerita yang berkaitan dengan keliling segitiga }\end{array}$ \\
\hline Level 2 & $\begin{array}{l}\text { - Menentukan hasil penjumlahan yang melibatkan satuan berat } \\
\text { - Menghitung perkalian bilangan } 3 \text { angka dengan bilangan } 2 \text { angka } \\
\text { - Menaksir hasil suatu perhitungan bilangan } \\
\text { - Menentukan faktor prima suatu bilangan } \\
\text { - Menentukan hasil penjumlahan yang melibatkan satuan panjang } \\
\text { - Menentukan hasil operasi perkalian dengan sifat asosiatif } \\
\text { - Menghitung keliling jajar genjang } \\
\text { - Menentukan faktor suatu bilangan } \\
\text { - Menentukan hasil penjumlahan yang melibatkan satuan kuantitas } \\
\text { - Menyelesaikan soal cerita yang berkaitan dengan satuan panjang }\end{array}$ \\
\hline Level 1 & $\begin{array}{l}\text { - Menentukan kelipatan suatu bilangan } \\
\text { - Menyetarakan satuan waktu windu ke dalam tahun } \\
\text { - Menyebutkan sudut siku-siku dari suatu bangun datar } \\
\text { - Mengurutkan bilangan dari yang terkecil } \\
\text { - Menentukan hasil operasi perkalian dengan sifat distributif } \\
\text { - Menentukan nilai posisi bilangan puluh ribuan }\end{array}$ \\
\hline & n rendah \\
\hline
\end{tabular}

604 - Jurnal Penelitian dan Evaluasi Pendidikan Tahun 16, Nomor 2, 2012 
Tes Matematika Kelas V terdiri 30 aspek kemampuan yang diujikan. Berdasarkan hasil identifikasi yang dilakukan diperoleh posisi level aspek-aspek kemampuan yang diujikan, sebagai berikut:

\section{Tabel 5. Hasil Tes Kelas V}

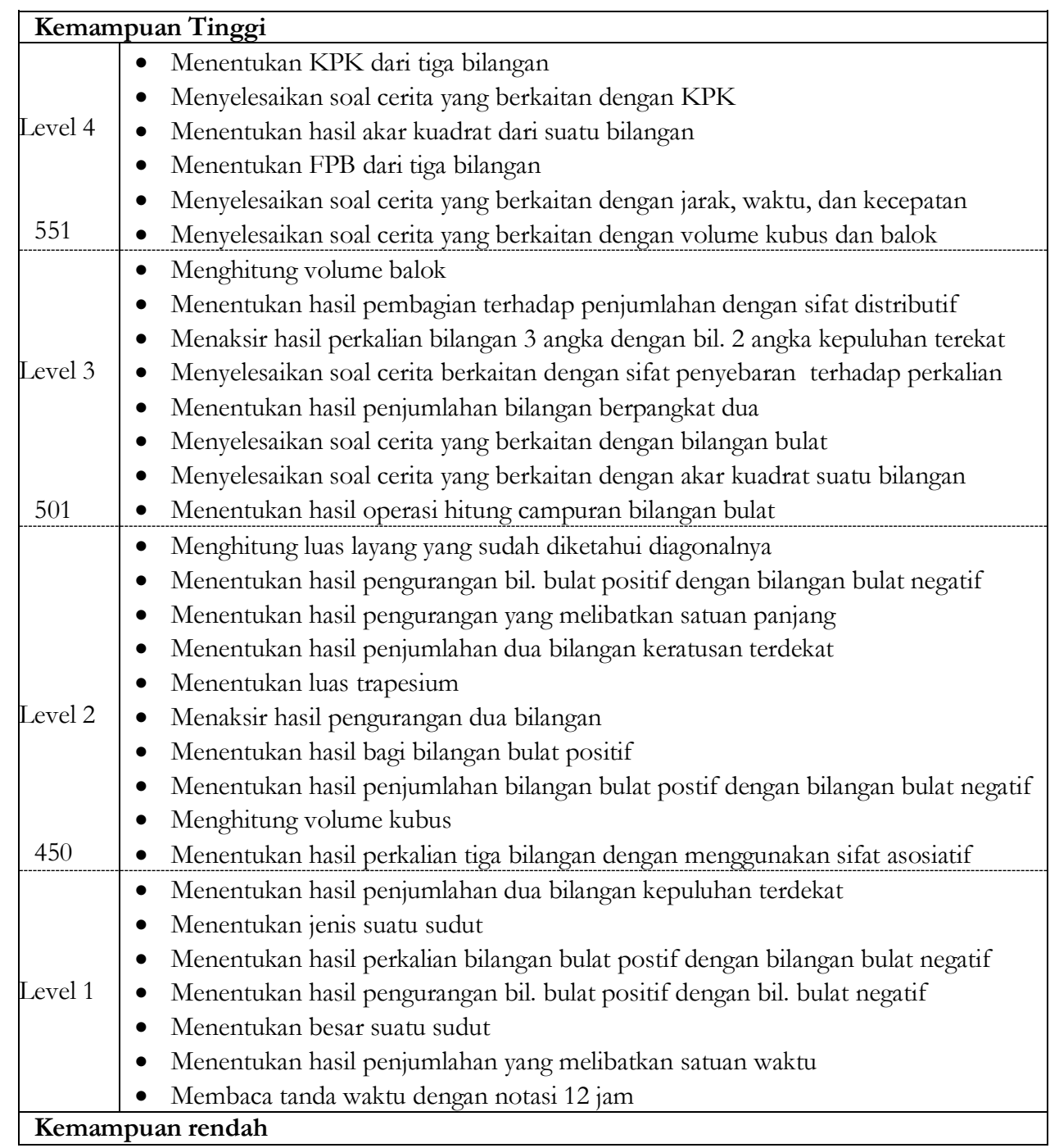


Posisi level aspek-aspek kemampuan yang diujikan pada Tes Matematika Kelas V diperoleh sebanyak 20,0\% Level IV, sebanyak 26,7,\% Level III, sebanyak 30,0 Level; II, dan 23,3\% Level I. Jumlah butir soal yang mengukur setiap level kemampuan untuk aspek kemampuan yang diujikan adalah: Level IV sebanyak 6 butir, Level III sebanyak 8 butir, Level II sebanyak 9 butir, dan Level I sebanyak 7 butir.

b. Posisi level kemampuan (ability) siswa

Seperti halnya level aspek-aspek kemampuan yang diujikan, kemampuan siswa juga dikelompokkan kedalam empat level kemampuan, yaitu : Level 1, Level 2, Level 3, dan Level 4. Dengan melakukan identifikasi berdasarkan kriteria yang digunakan diperoleh posisi level kemampuan siswa untuk masing-masing kelas. Berdasarkan hasil uji coba diperluas diperoleh posisi level kemampuan siswa menurut kelas dan level kemampuan adalah sebagai berikut.

Tabel 6. Jumlah Persentase Siswa Menurut Kelas dan Level Kemampuan

\begin{tabular}{|c|c|c|c|c|c|c|c|c|}
\hline \multirow{2}{*}{ Kelas } & \multicolumn{2}{|c|}{ Level I } & \multicolumn{2}{c|}{ Level II } & \multicolumn{2}{c|}{ Level III } & \multicolumn{2}{c|}{ Level IV } \\
\cline { 2 - 9 } & Jum & $\%$ & Jum & $\%$ & Jum & $\%$ & Jum & $\mathbf{\%}$ \\
\hline Kelas 3 & 86 & 21,50 & 125 & 31,25 & 109 & 27,25 & 80 & 20,00 \\
\hline Kelas 4 & 146 & 36,50 & 171 & 42,75 & 65 & 16,25 & 18 & 4,50 \\
\hline Kelas 5 & 129 & 32,25 & 185 & 46,25 & 18 & 4,50 & 68 & 17,00 \\
\hline Jumlah & 361 & 30,08 & 481 & 40,08 & 192 & 16,00 & 166 & 13,83 \\
\hline
\end{tabular}

Tabel di atas menunjukkan bahwa kecenderungan kemampuan siswa pada uji coba diperluas berada pada Level 1 dan Level 2, yakni sebanyak 70,17\%. Proporsi siswa yang memiliki kemampuan pada Level 1, Level 2, Level 3, dan Level 4 adalah: 0,3: 0,4: 02: 0,1. Kondisi ini berbeda dengan kemampuan siswa pada saat uji coba terbatas, dimana kecenderungan kemampuan siswa berada pada Level 2 dan Level 3. Proporsi siswa yang memiliki kemampuan pada Level 1, Level 2, Level 3, 
dan Level 4 adalah: 0,2: 0,4: 0,3: 0,1. Selanjutnya, deskripsi pencapaian nilai kemampuan siswa pada masing-masing kelas disajikan pada Tabel 4.

Tabel 7. Deskripsi Nilai Kemampuan Siswa

\begin{tabular}{|l|l|l|l|}
\hline Statistik & \multicolumn{1}{|c|}{$\begin{array}{c}\text { Siswa Kelas } \\
\text { III }\end{array}$} & $\begin{array}{c}\text { Siswa Kelas } \\
\text { IV }\end{array}$ & \multicolumn{1}{|c|}{$\begin{array}{c}\text { Siswa Kelas } \\
\text { V }\end{array}$} \\
\hline Minimum & 452 & 457 & 446 \\
\hline Maksimum & 597 & 699 & 660 \\
\hline Rerata & 523,15 & 528,76 & 525,92 \\
\hline Median & 518,20 & 526,85 & 512,29 \\
\hline Std. Deviasi & 39,521 & 45,753 & 59,575 \\
\hline
\end{tabular}

Berdasarkan tabel di atas terlihat bahwa rerata nilai kemampuan tertinggi dicapai pada siswa kelas IV disusul siswa kelas $\mathrm{V}$ dan terendah pada siswa kelas III. Nilai kemampuan tertinggi juga dicapai oleh siswa kelas IV disusul siswa kelas V dan terendah pada siswa kelas III. Namun demikian, bila dilihat dari segi posisi level kemampuan, nampaknya siswa kelas III mempunyai kemampuan lebih baik dari siswa kelas IV dan kelas V. Siswa kelas III yang memiliki kemampuan pada posisi Level III dan Level IV sebanyak 47,25\%, disusul kelas V sebanyak 21,50\% dan terakhir kelas IV hanya $20,75 \%$.

Pemetaan penguasaan siswa terhadap aspek-aspek kemampuan yang diujikan dilakukan untuk mengetahui letak kekuatan dan kelemahan siswa. Hal ini dilakukan oleh karena siswa yang memiliki level kemampuan yang sama belum tentu mempunyai kekuatan dan kelemahan yang sama. Oleh karena itu untuk mendeteksi dimana letak kelebihan dan kelemahan siswa, maka aspek-aspek kemampuan yang berhasil atau gagal yang dikuasi perlu dipetakan. Disamping itu, hasil dari pemetaan aspek kemampuan ini, juga dipakai untuk menyusun profil jawaban individu siswa. Untuk keperluan tersebut terlebih dahulu dibuat/disusun peta item (item map). 
Berikut ini diberikan salah satu sampel pemetaan aspek kemampuan yang dimiliki oleh seorang siswa yang bernama Istawati.

Siswa Istawati mempunyai kemampuan pada Level 2 dengan nilai skor kemampuan 548. Dengan berpedoman pada peta item, diperoleh aspek-aspek kemampuan yang berhasil dikuasi oleh Istawati, sebagai berikut:

Aspek kemampuan di Level 4

1) Menentukan hasil penjumlahan 2 bilangan 3 angka dengan teknik menyimpan

2) Menyelesaikan soal cerita yang melibatkan penjumlahan bilangan tiga angka

Aspek kemampuan di Level 3

3) Menyelesaikan soal cerita yang berkaitan dengan uang

4) Menentukan letak/posisi sekelompok bilangan pada garis bilangan

5) Menyelesaikan soal cerita yang berkaitan dengan satuan panjang

Aspek kemampuan di Level 2

6) Menentukan hasil operasi hitung perkalian dan penjumlahan

7) Menyatakan satuan tahun dalam satuan bulan

8) Menyelesaikan soal cerita yang melibatkan pembagian

9) Menentukan alat ukur yang digunakan sesuai dengan benda yang diukur

10) Menyatakan satuan $\mathrm{km}$ dalam satuan $\mathrm{m}$

11) Membaca waktu yang ditunjukkan pada sebuah jam

Aspek kemampuan di Level 1

12) Menyatakan satuan $\mathrm{kg}$ dalam $g$

13) Menentukan sebuah bilangan yang terletak di antara dua bilangan

14) Menentukan bilangan yang lebih besar dari dua bilangan

15) Menentukan bilangan dengan nilai posisi puluhan

16) Menentukan hasil penjumlahan 2 bilangan 3 angka tanpa teknik menyimpan 
Istawati berhasil menguasai 16 dari 26 aspek kemampuan yang diujikan, dengan perincian sebanyak 2 atau $50 \%$ dari 4 aspek pada Level 4 , 3 atau 33,3\% dari 9 aspek pada Level 3, 6 atau 85,7\% dari 7 aspek pada Level 2, dan 5 atau 83,3\% dari 6 aspek pada Level 1. Dengan demikian, kecenderungan penguasaan Istawati hanya pada Level 1 dan Level 2, dengan tingkat penguasaan $61,5 \%$. Aspek-aspek kemampuan yang belum dikuasai oleh Istawati ada 10 aspek, yaitu:

Aspek kemampuan di Level 4

1) Menyelesaikan soal cerita yang berkaitan dengan satuan berat,

2) menentukan hasil pengurangan dua bilangan tiga angka dengan teknik meminjam

Aspek kemampuan di Level 3

3) Menentukan hasil perkalian dua bilangan sampai tiga angka

4) menentukan hasil operasi hitung perkalian dan pembagian

5) Menyelesaikan soal cerita yang melibatkan operasi hitung campuran

6) Menyelesaikan soal cerita yang melibatkan satuan waktu

7) Menentukan hasil pembagian suatu bilangan 3 angka dengan bilangan 1 angka

8) Menghitung jumlah harga dari sekolompok barang tertentu

Aspek kemampuan di Level 2

9) Menyelesaikan soal cerita yang melibatkan perkalian

Aspek kemampuan di Level 1

10) Menuliskan nilai uang dengan benar

Hasil tes perlu dilaporkan kepada pihak-pihak yang berkepentingan agar dapat dinilai, dimaknai, dan dievaluasi. Model pelaporan hasil tes yang dikembangkan dalam penelitian mengadopsi model yang digunakan dalam The Basic Skill Testing Program (Masters, et al., 1990) dan Measurement and Teaching (Miller, 2008), tetapi dilakukan sejumlah perbaikan/revisi sesuai dengan kepentingan penelitian. Model pelaporan hasil tes terdiri dari dua bagian, yaitu: (1) laporan kepada sekolah (reports for schools) yang memuat 3 (tiga) komponen, yakni daftar nilai secara klasikal, daftar hierarki tingkat 
kesulitan aspek kemampuan yang diujikan, dan profil individu siswa (individual students profile). (2) laporan kepada orang tua (reports for parents) yang berisi informasi tentang nilai kemampuan, posisi level kemampuan, dan aspek-aspek kemampuan yang berhasil dan belum dikuasai oleh siswa dalam tes yang diujikan.

\section{Simpulan}

1. Model tes dan analisis prestasi belajar siswa yang dapat digunakan untuk melakukan identifikasi level kemampuan siswa dilakukan dengan mengikuti prosedur dan langkah yang meliputi 4 (empat) tahap, yaitu: pendahuluan, pengembangan tes, implementasi serta analisis dan penafsiran hasil tes.

2. Karakteristik tes yang digunakan untuk melakukan identifikasi level kemampuan siswa, sebagian besar soal-soalnya memiliki tingkat kesukaran sedang dan memiliki tingkat kehandalan tes dalam kategori cukup handal (konsisten).

3. Hasil identifikasi level kemampuan siswa menunjukkan bahwa sebagian besar siswa mempunyai kemampuan pada Level 1 dan Level 2, yakni sebanyak $70,17 \%$. Siswa yang mempunyai kemampuan pada Level 3 dan Level 4 hanya 29,83\%. Proporsi siswa yang memiliki kemampuan pada Level 1, Level 2, Level 3, dan Level 4 adalah: 0,3: 0,4: 02: 0,1. Ini berarti dalam 10 siswa ditemukan ada sekitar 4 orang yang memiliki kemampuan pada level 1, ada 3 orang yang memiliki kemampuan pada Lebel 2, ada 2 orang yang memiliki kemampuan pada Level 3, dan hanya 1 orang yang memiliki kemampuan pada Level 4. Temuan ini memberi indikasi bahwa perbaikan pembelajaran masih harus dilakukan oleh guru untuk meningkatkan kemampuan siswa dalam memahami materi pelajaran.

4. Dilihat dari segi level kemampuan, siswa kelas III mempunyai kemampuan yang lebih baik (lebih tinggi) dari dua kelas lainnya. Siswa kelas III yang memiliki kemampuan di Level 3 dan Level 4 sebanyak $47,25 \%$. Siswa kelas IV yang memiliki kemampuan di level 3 dan Level 
4 sebanyak 20,75\%. Siswa kelas V yang memiliki kemampuan di Level 3 dan Level 4 sebanyak 21,50\%.

5. Pelaporan hasil tes yang dapat dipakai untuk mendeskripsikan level pencapaian kompetensi siswa terdiri dari dua bagian, yaitu: (1) laporan kepada sekolah yang meliputi: laporan secara klasikal, daftar hierarki tingkat kesulitan aspek-aspek kemampuan yang diujikan, profil individu siswa; dan (2) laporan kepada orang tua yang berisi informasi tentang nilai kemampuan, posisi level kemampuan dan aspek-aspek kemampuan yang berhasil dan belum dikuasai oleh siswa dalam tes yang diujikan.

\section{Daftar Pustaka}

Anderson, L.W. 2003. Classroom assessment, enhancing the quality of teacher decision making. London: Lawrence Erlbaum Associates, Publishers.

Asmawi Zainul. 2004. Alternative assessment: Applied approach mengajar di perguruan tinggi. Jakarta: PAU-PPAI Universitas Terbuka.

Djemari Mardapi. Maret, 2004. Pengembangan sistem penilaian berbasis kompetensi. Makalah Disajikan dalam Seminar Nasional "Rekayasa Sistem Penilaian dalam Rangka Meningkatkan Kualitas Pendidikan" di Yogyakarta.

Herman, Aschbacher., \& Winters. 1992. Select or design assessments that elicut estabilished outcomes. Diambil pada tanggal 17 Juli 2006, dari http://www.norel.org/sdrs/areas/issues/methods/assement/as7ref s.htm.

Hopkins, D. 1992. A teacher's guide to classroom research. Philadelphia: Open University Press.

Jackson, N.,\& D'Andrea V. 2000. Benchmarking the outcomes of learning. Dalam Jackson, N., \& Lund, H. (Eds). Benchmarking for higer education. (pp 85-105). London: SHRE and Open University Press. 
Jurnal Penelitian dan Evaluasi Pendidikan

Masters, G.,Lokan, J., \& Doig, B., et al. 1990. Profiles of learning: the Basic skills testing program in New South Wales 1989. Hawton, Victoria: ACER.

Miller, P.W. 2008. Measurement and teaching. Indiana: Petrick W. Miller and associates Munster.

O’Malley, M.J., \& Pierce, L.V. 1996. Authentic assessment for english language learners. Practical approach for teachers.New York: Addison-Wesley Publishing Company.

Padmadewi. 2005. Asesmen berbasis kompetensi: Aplikasinya dalam pembelajaran keterampilan berbicara. Jurnal Pendidikan dan Pengajaran, 38(3), 455-472.

Popham, J.W. 1995. Classroom assessment what teachers need to know. Boston: Allyn and Bacon.

Tim Fasilitator. September, 2005. Pedoman asesmen berbasis kompetensi. Materi Pelatihan. Disampaikan pada Pelatihan Asesmen bagi Dosen-Dosen LPTK, di Yogyakarta. 